International Education Hubs 

Jane Knight

Editor

\section{International Education Hubs}

Student, Talent, Knowledge-Innovation Models

囪 Springer 


\author{
Editor \\ Jane Knight \\ Ontario Institute for Studies in Education \\ University of Toronto \\ Toronto, ON, Canada
}

ISBN 978-94-007-7024-9

ISBN 978-94-007-7025-6 (eBook)

DOI 10.1007/978-94-007-7025-6

Springer Dordrecht Heidelberg New York London

Library of Congress Control Number: 2013947123

(C) Springer Science+Business Media Dordrecht 2014

This work is subject to copyright. All rights are reserved by the Publisher, whether the whole or part of the material is concerned, specifically the rights of translation, reprinting, reuse of illustrations, recitation, broadcasting, reproduction on microfilms or in any other physical way, and transmission or information storage and retrieval, electronic adaptation, computer software, or by similar or dissimilar methodology now known or hereafter developed. Exempted from this legal reservation are brief excerpts in connection with reviews or scholarly analysis or material supplied specifically for the purpose of being entered and executed on a computer system, for exclusive use by the purchaser of the work. Duplication of this publication or parts thereof is permitted only under the provisions of the Copyright Law of the Publisher's location, in its current version, and permission for use must always be obtained from Springer. Permissions for use may be obtained through RightsLink at the Copyright Clearance Center. Violations are liable to prosecution under the respective Copyright Law.

The use of general descriptive names, registered names, trademarks, service marks, etc. in this publication does not imply, even in the absence of a specific statement, that such names are exempt from the relevant protective laws and regulations and therefore free for general use.

While the advice and information in this book are believed to be true and accurate at the date of publication, neither the authors nor the editors nor the publisher can accept any legal responsibility for any errors or omissions that may be made. The publisher makes no warranty, express or implied, with respect to the material contained herein.

Printed on acid-free paper

Springer is part of Springer Science+Business Media (www.springer.com) 
This book is dedicated to Ruth Hayhoe and Philip Altbach, both highly respected scholars and dear friends. This dedication not only honors their contribution to our field of comparative and international higher education but also acknowledges their role as mentors for the next generation of scholars, academic leaders, and policymakers. They have been highly influential and supportive in my own journey of understanding the international dimensions of higher education around the world. For that I extend my grateful appreciation and dedicate this book to them, and to future scholars working on the internationalization of higher education. 



\section{Contents}

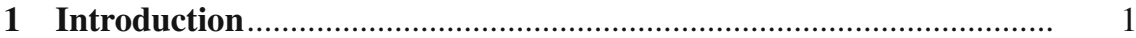
Jane Knight

2 Understanding Education Hubs Within the Context of Crossborder Education

Jane Knight

3 An Analytical Framework for Education Hubs

Jane Knight and Jack Lee

4 The Evolution of Qatar as an Education Hub:

Moving to a Knowledge-Based Economy

Arwa Ibnouf, Lois Dou, and Jane Knight

5 United Arab Emirates' Education Hub:

A Decade of Development

Warren Halsey Fox and Sabha Al Shamisi

6 Hong Kong: The Quest for Regional Education Hub Status

Ka Ho Mok and Peter Bodycott

7 Malaysia: Becoming an Education Hub

to Serve National Development

Mohd Ismail Abd Aziz and Doria Abdullah

8 Singapore: Building a Knowledge and Education Hub.

Ravinder Sidhu, Kong-Chong Ho, and Brenda S.A. Yeoh

9 Botswana Country Hub: Africa's First Education Hub

Bridget Poppy John, David Wilmoth, and Brian Mokopakgosi

10 Emerging Hubs: South Korea, Sri Lanka, Mauritius, and Bahrain

Lois Dou and Jane Knight 
11 Comparative Analysis of Education Hubs .................................. 183 Jane Knight

12 Education Hubs: Issues, Indicators and Reflections.................... 207 Jane Knight

About the Authors .......................................................................... 229

Comprehensive Bibliography and Sources of Further Information ......... 233

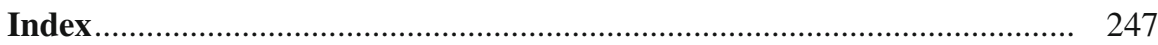

